\title{
Habitat preference of cockroaches in urban environments in Shanghai, China
}

\author{
Jing $Z_{\mathrm{HAI}}$ \\ Urban Pest Control Research Center, Department of Entomology, \\ Virginia Polytechnic Institute and State University, \\ Blacksburg, Virginia 24061-0319, U.S.A.
}

(Received: May 10, 1990)

Key words: Blattella germanica, Periplaneta fuliginosa, habitat preference, Shanghai.

\begin{abstract}
The habitat preference of domiciliary cockroaches in urban environments in Shanghai, China was evaluated with sticky traps. Residential houses $(N=40)$, one-room restaurants $(N=20)$ and hotel restaurants $(N=8)$ were sampled with 1 sticky trap $/ 15 \mathrm{~m}^{2}$, for 2 nights/month for 2 years. Blattella germanica was the most common $(96 \%)$ species trapped in hotel restaurants, and Periplaneta fuliginosa was the most common (94\%) cockroach trapped in households. $P$. americana was limited to $2-6 \%$ of the total cockroaches trapped in the three environments sampled. The one-room restaurant environment was intermediate in terms of heat, food, and water between the other two environments. B. germanica (76\%) and $P$. fuliginosa $(19 \%)$ were the most common species in one-room restaurants. The presence of German and smokybrown cockroaches in urban environments in Shanghai may be determined by availability of heat in buildings in winter, and abundance of food and water throughout the year. Hotel restaurants are heated in winter, and German cockroaches are common year round. Houses are not heated in winter and smokybrown cockroaches are most common during summer. In residences the number of smokybrown cockroaches trapped peaked in July 1987, and July and October 1988.
\end{abstract}

\section{INTRODUCTION}

Cockroaches are common pests in urban environments around the world. Nineteen species have been reported in urban buildings in The People's Republic of China (Woo, 1981, 1982, 1987; Woo and Guo, 1984; Chen et al., 1986; Robinson and Bao, 1988). The Periplaneta species: $P$. americana (L.), $P$. australasiae (F.), P. brunnea (Burmeister), and $P$. fuliginosa (Serville) are the most common cockroach pests in China. Blattella germanica (L.) and Blatta orientalis (L.) have a limited distribution in China (Robinson and Bao, 1988). Liang (1981) reported the distribution and infestation level of $P$. fuliginosa (as $P$. emarginata), $P$. americana, and $B$. germanica in Shanghai. $\mathrm{Xu}$ and Zhang (1983) also reported on the distribution and abundance of these three species over a four-month period in various buildings in Shanghai. Robinson and Bao (1988) reported the pest status of $P$. fuliginosa in apartments in Hangzhou, China. Although there are some data on the geographic distribution of pest cockroaches, there is little information on the distribution and seasonal 
abundance of the major cockroach pests in urban environments in China.

The objective of the research reported here was to determine habitat preferences of three domiciliary cockroach species in urban environments in Shanghai, China.

\section{Materials and Methods}

Study site. Shanghai (latitude $31 \mathrm{~N}$, longitude $121 \mathrm{E}$ ) has the second largest population of any city in the world, and the largest population of any city in China. There are approximately 12.5 million people living in $6,100 \mathrm{~km}^{2}$ in the Shanghai urban area. This coastal city has an average summer (JuneAugust) temperature of $28^{\circ} \mathrm{C}$, and an average winter (December-February) temperature of $3^{\circ} \mathrm{C}$.

Forty households, 20 one-room restaurants, and 8 hotel restaurants were selected for sampling. The majority of residential environments sampled were houses built adjacent to one another, forming one large building. The household sites contained two or three rooms. The majority of the houses were without a bathroom or running water indoors, and with kitchens located outside. The rooms were unheated in the winter.

The commercial environments sampled were one-room and hotel restaurants. The one-room restaurants were usually located in residential areas, with single- or multiplefamily dwellings adjacent to, or a part of them. Dining areas usually consisted of several small tables and chairs. These restaurants had running water indoors, but no bathroom facilities. A limited amount of heat in winter was provided by the kitchen and cooking activities. Hotel restaurants were large and isolated from residential build- ings. Kitchen areas had running water, large stoves and storage areas, and were heated in the winter months.

Sampling. Cockroach populations were sampled with sticky traps $(9 \times 15 \mathrm{~cm})$ baited with fresh bread, and placed 1 trap $/ 15 \mathrm{~m}^{2}$. Two traps were placed in each household room, four traps were used in each of the one-room restaurant kitchens, and five traps were placed in each hotel restaurant kitchen. The traps were set out for about $12 \mathrm{hr}(1900$ to 0700 ) each night on two successive nights. Traps were returned to the laboratory where the cockroaches were identified and counted. A small number of traps were not recovered each month.

Cockroach trapping was conducted from January 1987 through December 1988. Trapping data collected from June to December 1986 were used to select suitable sites and cooperators.

Insecticide use. A limited amount of cockroach-control insecticide was applied to the sites sampled. In hotel restaurants pyrethroid insecticides (aerosol) were applied approximately twice each month in 1988 and less regularly in 1987. In one-room restaurants and households there was limited insecticide use. In these locations pyrethroids were used only during summer months.

\section{Results and Discussion}

\section{Household environment}

The smokybrown cockroach, P. fuliginosa was the most common (94\%) cockroach in the households sampled (Table 1). P. americana was not common in households, and made up only $6 \%$ of the total cockroaches collected in this environment. The German cockroach, B. germanica, was not abundant

Table 1 Composition of the pest cockroach populations collected in households, one-room and hotel restaurants in Shanghai, China.

\begin{tabular}{lcrr}
\hline & \multicolumn{3}{c}{ Environment } \\
\cline { 2 - 4 } Species & $\begin{array}{c}\text { Households } \\
\text { No. }(\%)\end{array}$ & $\begin{array}{c}\text { One-room rest. } \\
\text { No. (\%) }\end{array}$ & $\begin{array}{c}\text { Hotel rest. } \\
\text { No. (\%) }\end{array}$ \\
\hline B. germanica & $20(0.8)$ & $3,765(75.9)$ & $15,379(95.8)$ \\
$P$. fuliginosa & $2,200(93.6)$ & $961(19.4)$ & $418(2.6)$ \\
$P$. americana & $131(5.6)$ & $235(4.7)$ & $261(1.6)$ \\
\hline
\end{tabular}


in the households sampled. It represented only about $1 \%$ of the total cockroaches collected in houses.

The dominance of $P$. fuliginosa in household environments in Shanghai may reflect its tolerance for warm and humid summer conditions, and cool and damp winter conditions (Yamaguchi, 1963; Tsuji and Mizuno, 1973; Tsuji, 1975; Appel and Tucker, 1984). The smokybrown cockroach probably can successfully overwinter in the unheated houses in Shanghai, and the German cockroach can not. Tsuji and Mizuno (1973) reported that the reason $B$. germanica was not common in Japanese houses, and that $P$. fuliginosa was a most common pest cockroach in Japan was due to the differences in their ability to overwinter in unheated buildings. $B$. germanica and $P$. americana were unable to survive 40 days at $5.5^{\circ} \mathrm{C}$, but middle and late instar nymphs of $P$. fuliginosa were able to survive 90 days at $5.5^{\circ} \mathrm{C}$ (Tsuji and Mizuno, 1973). Yamaguchi (1963) reported that the 3rd through the 7 th instar, and the adult smokybrown cockroach could survive in unheated buildings in winter.

The ability of the smokybrown cockroach to live both indoors and outdoors may be a factor in successful household infestations in Shanghai. This species has been reported to move between outdoor and indoor areas of residential and commercial structures (Appel and Tucker, 1984). Fleet and Frankie (1978) reported the home range of $P$. fuliginosa to be $177-401 \mathrm{~m}$. This species is capable of flying short distances, and can easily crawl or fly into houses to forage and oviposit (Appel and Tucker, 1984). Apartment residents questioned by Robinson and Bao (1988) reported $P$. fuliginosa flying into their apartments from outside.

The number of smokybrown cockroaches trapped in households fluctuated between summer and winter. From December to April very few smokybrown cockroaches were collected in households (Table 2). However, trap catches began to increase in May and the number trapped continued to increase in the following months, and peaked in August (Table 2). Smokybrown cockroach abundance corresponds to hot and humid weather (Takagi, 1974). Fleet and Frankie
(1978) reported that the population of $P$. fuliginosa increased when temperatures reached or exceeded $20^{\circ} \mathrm{C}$, and decreased when temperatures dropped below $20^{\circ} \mathrm{C}$ in southeast Texas. The number of smokybrown cockroaches trapped in urban buildings in Shanghai corresponded to variations of temperature during the year. The numbers of cockroaches trapped in households peaked in July and August when the temperatures were highest, and the fewest cockroaches were trapped in January when temperatures were lowest.

The occurrence of the German cockroach in the urban buildings sampled in Shanghai is consistent with the reported temperature and humidity preferences of this species. Cornwell (1968) reported the German cockroach preferred humid environments, and a temperature range of $24-33^{\circ} \mathrm{C}$. Ebeling et al. (1967) reported the importance of proximity of food and water to German cockroach survival. In urban areas in the United States the German cockroach is a common household pest throughout the year, with a preference for infesting kitchens and bathrooms (Akers and Robinson, 1981). This is probably because households in the U.S. are heated, and there is ample food and water

Table 2 Seasonal abundance of $P$. fuliginosa in households in Shanghai, China.

\begin{tabular}{lccccc}
\hline & \multicolumn{2}{c}{1987} & & \multicolumn{2}{c}{1988} \\
\cline { 2 - 3 } \cline { 5 - 6 } Month & $\begin{array}{c}\text { No. } \\
\text { trapped }\end{array}$ & Mean & & $\begin{array}{c}\text { No. } \\
\text { trapped }\end{array}$ & Mean \\
\hline Jan & - & - & & 0 & 0 \\
Feb & 3 & 0.02 & & - & - \\
Mar & 6 & 0.04 & & - & - \\
Apr & 5 & 0.03 & & 17 & 0.11 \\
May & 13 & $0.11^{*}$ & & 66 & $0.55^{*}$ \\
Jun & 51 & 0.32 & & 100 & 0.65 \\
Jul & 69 & 0.43 & & 152 & 0.98 \\
Aug & 38 & 0.24 & & 176 & 1.14 \\
Sep & 46 & 0.29 & & 130 & 0.84 \\
Oct & 23 & 0.14 & & 185 & 1.19 \\
Nov & 11 & 0.07 & & 35 & 0.23 \\
Dec & 2 & 0.01 & & 4 & 0.03 \\
\hline
\end{tabular}

* Based on 120 traps.

Based on an average of 155 (1988) to 159 (1987) traps. 
for cockroaches. In households sampled in Shanghai the conditions were not favorable for German cockroach survival. Dwellings were not heated in winter, and because of the absence of indoor water and cooking facilities, there may have been an inadequate amount of water and food available to support German cockroach infestations. Ogata (1976) reported that B. germanica adults and nymphs could not overwinter successfully in unheated buildings in Japan.

\section{One-room restaurants}

Nineteen percent of the cockroaches collected in this environment were $P$. fuliginosa. The German cockroach was common in hotel environments, and made up $76 \%$ of the cockroaches collected in the one-room restaurants sampled.

The one-room restaurant environment may have been intermediate between the austere (little food, water, and harborage) household environment, and the more favorable hotel restaurant environment. One-room restaurants had a limited amount of water available in the kitchen, and received some heat in winter. However, these restaurants are adjacent to houses in which food, water and heat were not available. Because of these limiting factors, German cockroach infestations in one-room restaurants may remain small.

\section{Hotel restaurants}

The German cockroach was the most common cockroach collected in this environment, $96 \%$ of the total cockroaches collected were this species. $P$. fuliginosa and $P$. americana were collected infrequently in this environment, and comprised only 3 and $2 \%$ of the total, respectively.

Hotel restaurants were heated in winter, had water available indoors, and probably contained ample food and harborage for domiciliary cockroaches. Large German cockroach infestations were common in this environment. Sources of this species in hotel restaurants may include boxes and packaging of imported food materials (Zhai, unpublished). These infestation sources can regularly provide additions to German cockroach populations in hotel restaurants.

\section{Acknowleneaments}

I am grateful to Mr. Fan Delin, Mr. Lu Zhixun, Mr. Yao Yanlin and Mr. Ma Shuzhen who cooperated with the cockroach trapping in Shanghai. I appreciate the helpful comments by Dr. William $\mathrm{H}$. Robinson and Mr. Nonggang Bao, VPI and $\mathrm{SU}$, in preparing this manuscript. Dr. Patricia A. Zungoli, Entomology Department, Clemson Univ., reviewed and improved the manuscript.

\section{REFERENCES}

Akers, R. C. and W. H. Robinson (1981): Spatial patterns and movement of German cockroaches in urban low-income apartments (Dictyoptera: Blattellidae). Proc. Entomol. Soc. Wash., 83: 168-172.

Appel, A. G. and J. B. Tucker (1984) : Bionomics and control of the smokybrown cockroach. Pest Management, 3 (12): 10-13, 38.

Chen, P., C. Huang, P. Su and J. Huang (1986) : Report on cockroach species, biology and habits in Nanning, Guangxi. In: Studies on Household Cockroaches and Bedbugs, Series 3, Medical Animal Pest Control (ed., Huang, Z.), Vol. 2, No. 4, pp. 16-24.

Cornwell, P. B. (1968) : The Cockroach, 365 pp., Hutchinson \& Co., London.

Ebeling, W., D. A. Reierson and R. E. Wagner (1967): Influence of repellency on the efficacy of blatticides. II. Laboratory experiments with German cockroaches. J. Econ. Entomol., 60: 1375-1390.

Fleet, R. R. and G. W. Frankie (1978): Studies on the population ecology of the smokybrown cockroach, Periplaneta fuliginosa, in a Texas outdoor urban environment. Environ. Entomol., 7: 807-814.

Liang, T. (1981): Survey of infestation, composition and habitats on three common indoor cockroaches in Shanghai. In: Studies on Household Cockroaches and Bedbugs, Series 1, pp. 23-25.

Ogata, K. (1976): Studies on establishing factors of domiciliary cockroaches 2. Experimental observations of development of German cockroaches in various environments. Jpn. J. Sanit. Zool., 27: 411-421.

Robinson, W. and N. Bao (1988) : The pest status of Periplaneta fuliginosa (Serville) (Dictyoptera: Blattidae) in China. Proc. Entomol. Soc. Wash., 90: 401-406.

Takagi, M. (1974): Ecological studies on the smokybrown cockroach, Periplaneta fuliginosa S. I. Seasonal change of the numbers and age structure of a natural population, and the dis- 
tribution in a house. Jpn. J. Sanit. Zool., 25: 27-34.

'Tsuji, H. (1975): Development of the smokybrown cockroach, Periplaneta americana, in relation to resistance to cold. Jpn. J. Sanit. Zool., 26: $1-6$.

Tsuji, H. and T. Mizuno (1973): Effects of a low temperature on the survival and development of four species of cockroaches, Blattella germanica, Periplaneta americana, $P$. fuliginosa, and P. japonica. Jpn. J. Sanit. Zool., 23: 185194.

Woo, F.-C. (1981): Blattoptera: Corydidae, Blattidae, Panesthiidae. Insects Xizang (Tibet), 1: 57-61.

Woo, F.-C. (1982): Species of the genus Periplaneta (Burmeister) from China, with reference to their bionomics and economic importance (Blattaria: Blattidae). Acta Entomol. Sinica, 25: 416-422.

Woo, F.-C. (1987): Investigations on domiciliary cockroaches from China. Acta Entomol. Sinica, 30: 430-438.

Woo, F.-C. and Y. Guo (1984): The specific identification, distribution, bionomics, and economic importance of the genus Blattella Caudell (Blattaria: Blattidae) from China. Acta Entomol. Sinica, 27: 439-442.

$\mathrm{Xu}, \mathrm{Y}$. and Y. Zhang (1983): The survey on distribution of cockroach populations in 50-unit of Shanghai railway. In: Studies on Household Cockroaches and Bedbugs, Series 2, pp. 47-50.
Yamaguchi, A. (1963): Ecological notes on the cockroaches in Kyoto (1) Observations on overwintering of Periplaneta fuliginosa, P. brunnea, and Blattella germanica. Jpn. J. Sanit. Zool., 14: 126.

\section{摘要 \\ 上海の都市環境におけるゴキブリの 生息場所の選択}

上海の都市環境に生息する家住性ゴキブリの生息場 所の選択について，集合住宅，ワンルームレストラン， およびホテルレストランにおいて 1 カ月に 2 日間, 粘 着トラップを $15 \mathrm{~m}^{2}$ に 1 トラップの割合で配置して, 2 年間調查を行った.

ホテルレストランでは，チャバネゴキブリが全捕獲 数の 96\%を占めたのに対し，集合住宅では 94\%がク ロゴキブリであった．ワモンゴキブリはいずれの環境 下でも 2〜6\%しか捕獲されなかった。 ワンルームレ ストランは, 温度, 食料, 水との関係で他の場所との 中間的な環境であり，チャバネゴキブリは $76 \%$ ， ク ロゴキブリは $19 \%$ 捕獲された.

上海の都市環境におけるチャバネゴキブリとクロゴ キブリの生息は，冬季のビル内の温度条件や年間を通 じての豊富な食料と水によって決定されると思われ， ホテルレストランは冬季加温されるのでチャバネゴキ ブリが周年見られる. また冬季加温されない集合住宅 ではクロゴキブリが夏期の閒最も普通に見られ，捕獲 数は1987年では 7 月に，1988年では 7 月と10月にピー クを示した. 